\title{
Cloning and Characterization of the Antigenic Membrane Protein (Amp) Gene and In Situ Detection of Amp from Malformed Flowers Infected with Japanese Hydrangea Phyllody Phytoplasma
}

\author{
R. Arashida, S. Kakizawa, Y. Ishii, A. Hoshi, H.-Y. Jung, S. Kagiwada, Y. Yamaji, K. Oshima, and S. Namba
}

First, second, third, fourth, sixth, seventh, eighth, and ninth authors: Laboratory of Plant Pathology, Department of Agricultural and Environmental Biology, Graduate School of Agricultural and Life Sciences, The University of Tokyo, 1-1-1Yayoi, Bunkyo-ku, Tokyo 113-8657, Japan; and fifth author: Laboratory of Fungal Plant Pathology, Department of Agricultural Biology, College of Agriculture and Life Sciences, Kyungpook National University, 1370 Sangyeok3-dong, Buk-gu, Daegu, 702-701 Korea.

Accepted for publication 20 February 2008.

\begin{abstract}
Arashida, R., Kakizawa, S., Ishii, Y., Hoshi, A., Jung, H.-Y., Kagiwada, S., Yamaji, Y., Oshima, K., and Namba, S. 2008. Cloning and characterization of the antigenic membrane protein (Amp) gene and in situ detection of Amp from malformed flowers infected with Japanese hydrangea phyllody phytoplasma. Phytopathology 98:769-775.

A Japanese hydrangea phyllody (JHP) disease found throughout Japan causes economic damage to the horticultural industry. JHP phytoplasmainfected Japanese hydrangea plants show several disease symptoms involved in floral malformations, such as virescence, phyllody and pro-

expressed the JHP-Amp protein in Escherichia coli cells, and then obtained an antibody against JHP-Amp. The antibody against JHP-Amp had no cross-reactions with the antibody against the Amp protein from a closely related onion yellows phytoplasma. This serologic specificity is probably due to the high diversity of the hydrophilic domains in the Amp proteins. The in situ detection of the JHP-Amp protein revealed that the JHP phytoplasma was localized to the phloem tissues in the malformed flower. This study shows that the JHP-Amp protein is indeed a membrane protein, which is expressed at detectable level in the JHP phytoplasmainfected hydrangea.
\end{abstract} liferation. Here, we cloned and characterized the antigenic membrane protein (Amp) gene homolog from the JHP phytoplasma (JHP-amp),
Additional keywords: immunodominant membrane protein, mollicutes.
Phytoplasmas are economically important plant pathogens that are associated with diseases in over hundreds of plant species $(20,25)$. They produce a wide variety of symptoms in host plants, including virescence (greening of floral tissue), chlorosis, phyllody (changing of floral parts into leafy structures), stunting and proliferation (witches'-broom) $(22,36)$. Phytoplasmas are intracellular within both plant phloem and insect cells, and are transmitted from plant to plant by insect vectors. Despite their economic importance and unique biological features, phytoplasmas remain among the most poorly characterized plant pathogens, primarily because efforts at in vitro culture, gene delivery, and mutagenesis have been unsuccessful. However, the complete genomic sequences of 'Candidatus Phytoplasma asteris' OY (onion yellows) strain and AY-WB (aster yellows witches'broom) strain have shed light on their unique genomic evolution $(2,29)$. The phytoplasma genomes encode even fewer metabolic proteins than mycoplasmas. Phytoplasmas probably lost many biosynthesis genes as a result of reductive evolution following adaptation to an intracellular environment.

The Japanese hydrangea phyllody (JHP) phytoplasma-infected Japanese hydrangea plants show several disease symptoms involved in floral malformations, such as virescence, phyllody, and proliferation. Kanehira and co-workers (19) reported the occurrence of JHP disease in Japan, and suggested that the causal agent was a phytoplasma. The JHP disease occurs all over Japan and damages the horticultural industry. However, it is difficult to prevent the dissemination of the disease because the insect

Corresponding author: S. Namba; E-mail address: anamba@mail.ecc.u-tokyo.ac.jp

doi:10.1094/PHYTO-98-7-0769

(C) 2008 The American Phytopathological Society vector(s) of the JHP phytoplasma have not been identified. To date, the JHP phytoplasma has only been found in Japan. Phyllody and virescence diseases of the hydrangea plants have been reported in many countries, such as Italy (6), Belgium (40), France (11), and Canada (13). However, the causal phytoplasmas of these diseases were classified into the aster yellows type (subgroup Ia) phytoplasmas based on 16S rDNA gene sequences, whereas the JHP phytoplasma was classified into subgroup Id (34). From this phylogenetically unique feature, the JHP phytoplasma was designated as a new species, 'Candidatus Phytoplasma japonicum' (34).

It is interesting to study the molecular mechanisms involved in the symptoms of phytoplasma infections, especially symptoms with floral abnormalities, such as virescence, phyllody, and proliferation. In a recent study on flower malformations caused by a phytoplasma, Pracros and co-workers (32) demonstrated that the five flower development genes were misregulated in the stolbur phytoplasma-infected tomatoes. However, the mechanisms of flower abnormalities induced by a phytoplasma are still unknown, and it is also unclear through which tissue phytoplasmas influence the flower development. To answer this question, several attempts have been made to examine the distribution of a phytoplasma in plant tissues. For example, lethal yellowing phytoplasma in fruits of coconut was detected by in situ PCR to examine the possible potential for seed transmission of the phytoplasma (10), and the mulberry dwarf (MD) phytoplasma in the reproductive organs of mulberry trees was detected by direct or nested PCR to clarify the possibility of seed transmission (14). In these previous works, the PCR method was used to investigate the presence of phytoplasmas in the organs of the host plants. However, immunolocalization analysis with an antibody against phytoplasma is also useful in examining the distribution patterns of phytoplasmas in infected tissues. 
For the sensitive detection of phytoplasmas, an antibody raised against a phytoplasma membrane protein can be a useful tool. In most phytoplasmas, a single membrane protein, termed the immunodominant membrane protein (IDP), exists abundantly in cell preparations (35). Genes encoding IDPs have been isolated from several groups of phytoplasmas, and it has been suggested that the IDPs are classified into three distinct types: (i) immunodominant membrane protein (Imp); (ii) immunodominant membrane protein A (IdpA); and (iii) antigenic membrane protein (Amp) (17). These IDPs are nonhomologous because they show no amino acid similarity, are located on different parts of the genome and their predicted transmembrane structures differ greatly (17). Antigenic membrane protein (Amp), one of the IDP types, is composed of three domains: an N-terminal signal leader domain that is processed by the secretory translocation system, a large hydrophilic domain that is exposed to the host cytoplasm, and a C-terminal transmembrane domain $(3,16)$. Since the specific and sensitive detection of phytoplasmas was performed with antibodies against the IDPs, the antibody against Amp is expected to be a good tool for detection, diagnosis, and other experiment techniques for phytoplasmas $(3,5)$.

In this study, we cloned and characterized the amp gene homolog from the JHP phytoplasma, expressed the JHP-Amp protein in Escherichia coli cells, and then obtained an antibody against JHPAmp. With the use of this antibody, we performed the in situ detection of the JHP-Amp protein in infected floral tissues. Our results confirmed that the JHP phytolasmas inhabit exclusively in phloem cells. The relationship between the localization of phytoplasma in phloem cells and the abnormal flower development is discussed.

\section{MATERIALS AND METHODS}

Plant materials. The healthy and the JHP phytoplasmainfected hydrangea plants (Fig. 1) used for cloning the JHPamp gene and for western blot analysis were obtained from a field in Saitama Prefecture, Japan. The JHP phytoplasmainfected hydrangea plants used for morphological observations and immunolocalization analysis were provided by the Nippon Hydrangea Association. The OY-W used in this study was isolated in 1982 in Saga Prefecture, Japan (36). Healthy and the OY-W-infected garland chrysanthemum (Chrysanthemum coronarium) plants were maintained in greenhouses with the leafhopper vector, Macrosteles striifrons. Total DNA was extracted from tissues of the hydrangea plants using previously described methods (27).

Cloning and sequence analysis of the JHP-amp gene. A series of previously designed primers for the amplification of the OY amp gene (15) was used to clone the JHP-amp gene. The PCR amplification for the JHP-amp gene was performed under previously described conditions (15). As a result, DNA fragments containing the JHP-amp gene were amplified with the several primer pairs. Amongst these, the largest fragment was amplified using the ES-1 primer: 5'-TTG AGC TCG CGG CCG CAT GAA ACA AAA AAC AAT TAT C-3' and Nad-2 primer: 5'-TTT GCC TGA TTG AAA CCA TCT- $3^{\prime}$. This amplified fragment was purified using ExoSAP-IT(R) (GE Healthcare, Milwaukee, WI) and then sequenced directly with the EL-3 primer (5'-TAT CAA GAA TTA AAA GAT ACT-3') and Nad-2 primer. The JHP-amp sequence was completed by the primer-walking method using the JHPAmp-F primer (5'-AGA ATT CCA TAT GCA AAA CGT TAA AAC TAA AAA ATC-3') and the JHP-Amp-R primer (5'-GAA AAA GCT AGA TTA AAA ACC TAG C-3'). Each ORF was analyzed with the standard genetic code, and annotated with the BLAST algorithm (1). The multiple alignments of the partial groEL, the intergenic sequence 1 (IGS1), the amp gene, the Amp protein, the intergenic seqeunce 2 (IGS2), the partial nadE from OY-W, OY-M, AY-C, AY-WB, CP, and JHP phytoplasmas
(GenBank accession nos. AB124806, AB124807, AF244540, AF244540, and JHP AB355409, respectively) were performed using ClustalW (38). Sequence identities were then calculated using GeneDoc (28). The putative transmembrane domain in the predicted protein sequence was identified with the SOSUI program (12). The N-terminal signal sequence was predicted using the SignalP 3.0 program (4).

Preparation of antiserum against the JHP-Amp protein. The pET system (Novagen, Madison, WI) was used for the expression of the histidine-tagged JHP-Amp in E. coli. The JHPAmp gene consisted of an $\mathrm{N}$-terminal export signal sequence ( $a m p-\mathrm{E})$, a central hydrophilic domain sequence $(a m p-\mathrm{H})$ and a C-terminal transmembrane sequence with a short hydrophilic domain ( $a m p$-T) (Fig. 2). For the expression of the $a m p$ gene with a six-histidine tag at the C-terminal end, we designed three constructs: an intact $a m p$ gene $(a m p-\mathrm{E} / \mathrm{H} / \mathrm{T})$, an $a m p$ gene without amp-T (amp-E/H) and an $a m p$ gene $(a m p-\mathrm{H})$ with only the hydrophilic domain. The $a m p-\mathrm{E} / \mathrm{H} / \mathrm{T}$ constructs were amplified by PCR using the JHP-Amp-F primer and the JHP-Amp-R2 primer ( $5^{\prime}$ AAG AGC TCG AGC GCT TGT TGT CTT TTT TTA TC-3'). The $a m p-\mathrm{E} / \mathrm{H}$ construct was amplified by PCR using the primers JHP-Amp-F and JHP-Amp-CR (5'-AAG AGC TCG AGT TTT TTG TAA AAC GGC GTT GC-3'). The amp-H construct was amplified by PCR using the primers JHP-Amp-NF (5'-AGA ATT CCA TAT GTT TGG TGA TGC AAA ATT ACC ATC-3') and JHP-Amp-CR. Following a previously described procedure (17), a soluble fraction of crude extract of E. coli expressing JHP-Amp$\mathrm{H}$ was applied to a nickel column to purify the histidine-tagged protein. The purity of the JHP-Amp-H protein was checked by sodium dodecyl sulffate-polyacrylamide gel electrophoresis (SDSPAGE). One milligram of the purified JHP-Amp-H protein was used to immunize a rabbit. Antibodies against the JHP-Amp protein were emulsified with 1:1 volume of Freund's complete adjuvant (Difco, Detroit, MI). The rabbit was boosted with a second injection after 2 weeks. The IgG fractions were purified from the crude serum with a Protein A column (Bio-Rad, Kanagawa, Japan).

SDS-PAGE and western blot analysis. Fresh leaf tissue from healthy or the phytoplasma-infected plants was frozen in liquid nitrogen and ground with a mortar and pestle. Extraction buffer (30 mM Tris/HCl buffer (pH6.8), 2\% SDS, and 6\% mercaptoethanol) was added, and then boiled at $95^{\circ} \mathrm{C}$ for $5 \mathrm{~min}$. After centrifugation $(18,000 \mathrm{~g}, 15 \mathrm{~min})$, the supernatant was separated by SDS-PAGE. Western blotting was then applied following a previously described method (16) with some modifications. A $15 \%$ polyacrylamide gel was used for SDS-PAGE with an ECL(R) plus western blotting detection system (GE Healthcare). After incubation with the first antibody, the membranes were washed with TBST (20 mM Tris/ $\mathrm{HCl}$ (pH7.9), $500 \mathrm{mM} \mathrm{NaCl}$, and Tween 20), and reacted with a horseradish peroxidase-linked anti-rabbit IgG (from donkey) (GE Healthcare) diluted 1:5,000 in TBST. The proteins were detected with ECL(R) plus western blotting detection reagents (GE Healthcare) according to the manufacturer's instructions, and visualized with a luminescence image analyzer (LAS1000; FujiFilm, Tokyo, Japan).

Immunolocalization analysis. Using an antibody against JHPAmp, immunolocalization analysis was carried out following a previously described procedure (18). Briefly, approximately $1-\mathrm{cm}^{2}$ pieces of carpels with stamens and petals were excised from the healthy and the JHP phytoplasma-infected hydrangea plants. Tissues were fixed in $4 \%$ (wt/vol) paraformaldehyde and $0.25 \%$ glutaralldehyde in $0.1 \mathrm{M}$ sodium phosphate buffer ( $\mathrm{pH} 7.4$ ) overnight at $4{ }^{\circ} \mathrm{C}$, dehydrated first through a graded ethanol series and then a 2-methyl-2-propanol series (33). Fixed tissues were embedded in paraffin and sliced to $8-\mu \mathrm{m}$ thickness with a microtome (PR-50; Yamato Scientific, Tokyo, Japan). The localization of JHP-Amp in each tissue was detected with an alkaline phosphatase-mediated reporter system (18). 


\section{RESULTS}

Flower abnormalities in the JHP phytoplasma-infected hydrangea. It has been reported that the hydrangea plants infected with the JHP phytoplasma show the floral organ abnormalities (19). The part generally called the flower of hydrangea plants is an ornamental flower, not a true flower. The organ that looks like a petal is actually a sepal, and the true petal is a central small organ (Fig. 1A, E, and I). The JHP phytoplasma-infected hydrangeas have three distinct kinds of the disease symptoms: virescence, phyllody, and proliferation. In the infected hydrangea flowers that showed virescence, although the sepals were green, other floral organs remained normal (Fig. 1B, F, and J). In the infected hydrangea flowers that showed phyllody, the sepals changed into leaf-like structures, and the petals were green (Fig. 1C). Moreover, the stamens were filamentous (Fig. 1G), the stigma changed into a leaf and the ovary disappeared (Fig. 1K). In the infected hydrangea flowers that showed proliferation, in addition to features of phyllody, the pistil changed into the shoot apex (Fig. 1D, H, and L, arrow), suggesting that the flower development reverted to a vegetative developmental stage.

Cloning and characterization of the JHP-amp gene. To clone the amp gene homolog from the JHP phytoplasma, various pairwise combinations of the primers designed for amplification
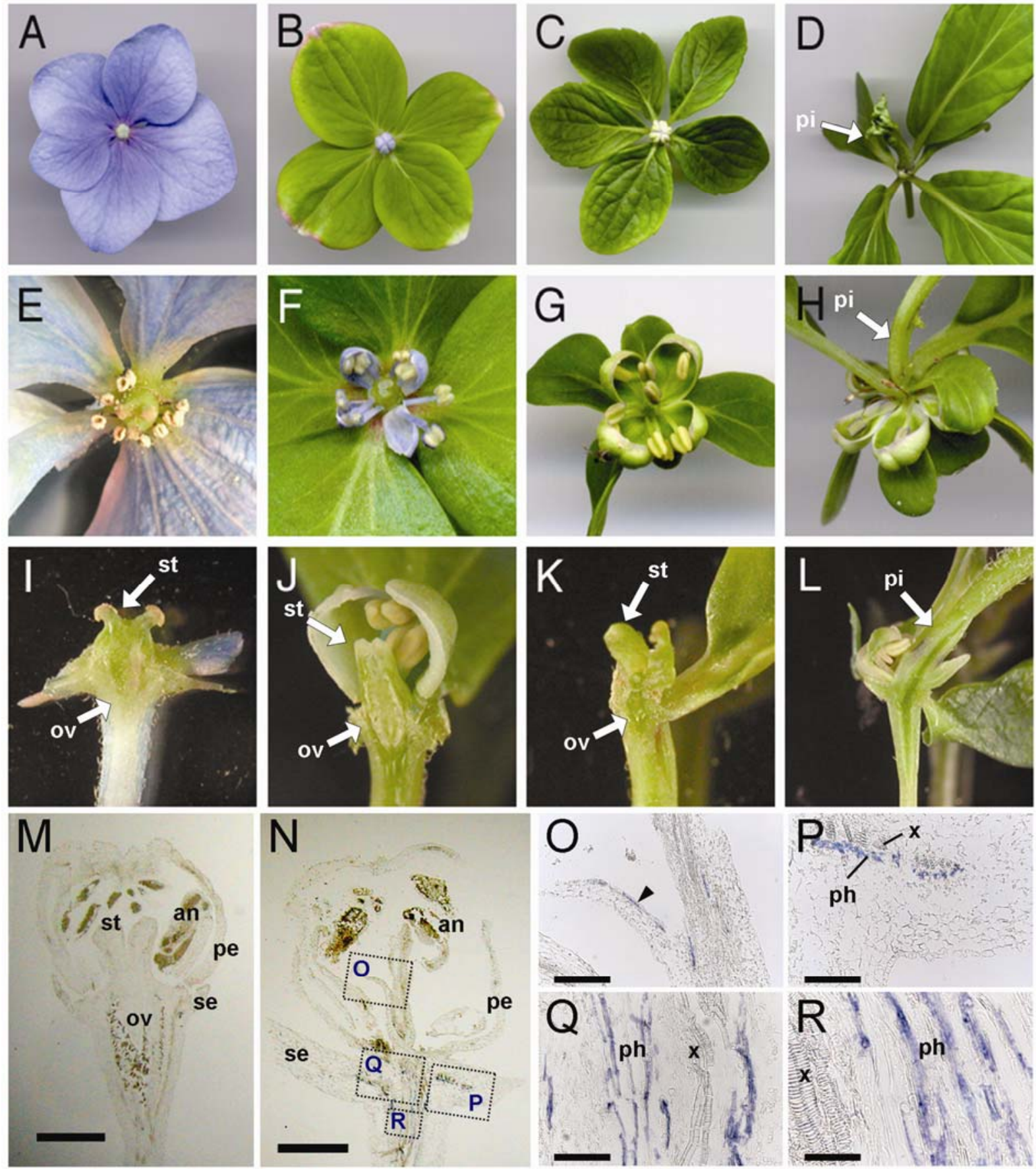

Fig. 1. Healthy ornamental flower of Japanese hydrangea (A, E, and I), and Japanese hydrangea phyllody (JHP) phytoplasma-infected plants (B, C, D, F, G, H, J, $\mathbf{K}$, and $\mathbf{L}$ ). Sepal greening and normal corolla (virescence: $\mathbf{B}, \mathbf{F}$, and J), leaf-like sepal and greening petal (phyllody: $\mathbf{C}$, G, and $\mathbf{K}$ ), and stem-like pistil (proliferation: D, H, and $\mathbf{L}$ ). Immunolocalization analysis of transverse sections through carpels, petals, and stamens of $\mathbf{M}$, healthy and $\mathbf{N}$, Japanese hydrangea phyllody-phytoplasma-infected plants. $\mathbf{O}$ to $\mathbf{R}$, Magnified images in $\mathbf{N}$. An arrowhead indicates the signals in a leaf-like stigma. Abbreviations: ov = ovary; st = stigma; an = anther; pe = petal; se = sepal; ph = phloem; $\mathrm{x}=$ xylem. Scale bars: $\mathbf{M}, \mathbf{N}, 1.0 \mathrm{~mm} ; \mathbf{O}, \mathbf{P}, \mathbf{Q}, 200 \mu \mathrm{m} ; \mathbf{R}, 50 \mu \mathrm{m}$. 
of the OY amp genes (15) were tested in PCR with DNA extracted from the JHP phytoplasma-infected hydrangea plants as a template. As a result, the DNA fragments containing the JHP-amp gene were amplified with several primer pairs, and the largest fragment was directly sequenced. The 1,551-bp fragment contained one complete ORF and two incomplete ORFs. BLAST search analysis suggested that the first incomplete ORF encoded a protein that was similar to part of the molecular chaperonin, GroEL ( $g r o E L$ ), and the third incomplete ORF encoded a protein that was similar to the part of an NAD synthase ( $n a d E$ ) (Fig. 2A). The second ORF (474 bp) was identified as an $a m p$ gene from the JHP phytoplasma (JHP-amp) because BLASTP analysis showed a weak similarity (48\%) to the amp gene from AY-WB, and the gene organization around amp, 5'-groEL-amp-nadE-3', was

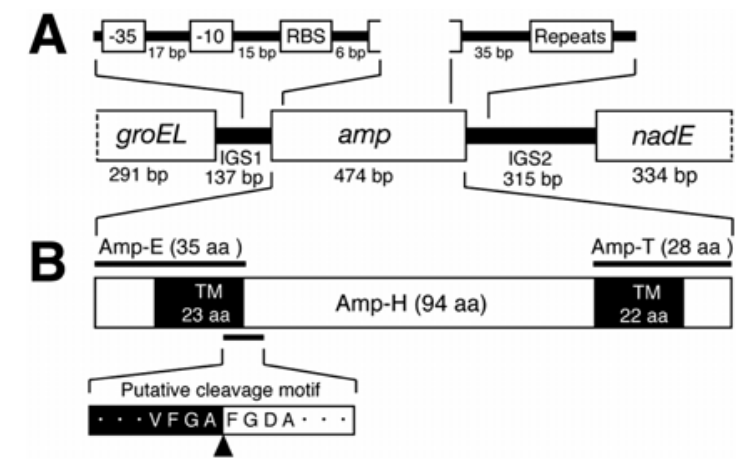

Fig. 2. Schematic representation of the open reading frames (ORF) and other features for the Japanese hydrangea phyllody (JHP) phytoplasma sequences (A) and putative antigenic membrane protein (Amp) translation products (B). -35 and -10 , possible transcription signals; RBS, putative ribosome-binding site; Repeats, short inperfect inverted repeats; groEL, molecular chaperonin GroEL gene; amp, antigenic membrane protein gene; nadE, NAD synthase gene; IGS1 and IGS2, intergenic sequences 1 and 2; Amp-E, N-terminal export leader sequences; Amp-H, major hydrophilic domain; Amp-T, transmembrane/short C-terminal hydrophilic domain; TM, transmembrane predicted by the SOSUI program (12). Putative cleavage motif was predicted by the SignalP 3.0 program (4) and is indicated by an arrowhead. highly conserved in several strains of the AY subclade phytoplasmas $(2,3,17,30)$.

We characterized the nucleotide sequence and the deduced amino acid sequence of the JHP-amp gene in detail. The $\mathrm{G}+\mathrm{C}$ content of the amp ORF (31.7\%) was high compared to the average $\mathrm{G}+\mathrm{C}$ content of the 1,551-bp whole fragment (26.0\%). A putative ribosome-binding site (AAAGGAA) and transcription signals (-35; TTGTTT: -10 ; ACAAAT) were found in the upstream region of the translation start codon (IGS1: intergenic sequence 1). A putative transcription terminator was found as the short imperfect inverted repeats (5'-AAAAAGCTAGGTT-TTTAATCTAGCTTTTT-3') in the intergenic sequence 2 (IGS2) (Fig. 2A). The putative amino acid sequence encoded by the JHP-amp gene (JHP-Amp) was 157 aa in length, which is approximately the same length as CP Amp (164 aa) and AY-WB Amp (164 aa), but smaller than AY Amp (233 aa), OY-M Amp (234 aa), and OYW Amp (233 aa). JHP-Amp was rich in lysine (14.6\%), valine $(12.7 \%)$, and alanine $(12.4 \%)$. Two transmembrane regions were predicted in the $\mathrm{N}$-terminal and the $\mathrm{C}$-terminal regions of JHPAmp (Fig. 2B). The putative cleavage motif of the Sec transport system was predicted at the border between the N-terminal transmembrane domain and the hydrophilic domain (Fig. 2B). These results indicate that JHP-Amp consists of three domains: an $\mathrm{N}$-terminal export leader sequence (Amp-E), a large hydrophilic domain (Amp-H), and a transmembrane $\mathrm{C}$-terminal hydrophobic domain (Amp-T) (Fig. 2B). This secondary structure is the same as that of other previously reported Amp proteins $(3,16)$.

Sequence comparisons of the amp genes and flanking DNA sequences. To describe the protein sequence identities, we then compared the sequence identity of each domain of JHP-Amp with the Amps from five AY subclades phytoplasmas (Table 1). As previously described, the percent identities of the three domains of Amp were different from each other $(3,26)$. Amongst the five AY subclade phytoplasmas, sequence identities of Amp-E, Amp$\mathrm{H}$, and Amp-T ranged from 72 to $100 \%, 30$ to $97 \%$, and 67 to $100 \%$, respectively (Table 1). These data indicate that both the Amp-E and the Amp-T domains were well conserved, but the Amp-H domain was diverse. The comparison of the Amp between

TABLE 1. Sequence identities (\%) for three parts of the $a m p$ gene orthologs and their putative translation products from Japanese hydrangea phyllody (JHP) and five aster yellows (AY) group phytoplasmas (below, left), nucleotide sequence identities (\%) for intergenic sequence 1 (IGS1), IGS2, and nadE (above, right)

\begin{tabular}{|c|c|c|c|c|c|c|c|c|c|}
\hline Strain $^{\mathrm{a}}$ & Gene & Domain & JHP & OY-W & OY-M & AY-C & AYWB & $\mathrm{CP}$ & \\
\hline JHP & & & $\begin{array}{l}- \\
- \\
-\end{array}$ & $\begin{array}{l}60 \\
49 \\
80\end{array}$ & $\begin{array}{l}59 \\
49 \\
78\end{array}$ & $\begin{array}{l}59 \\
49 \\
78\end{array}$ & $\begin{array}{l}61 \\
47 \\
81\end{array}$ & $\begin{array}{l}61 \\
46 \\
79\end{array}$ & $\begin{array}{l}\text { IGS } 1^{\mathrm{b}} \\
\text { IGS2 }^{\mathrm{b}} \\
\operatorname{nadE}^{\mathrm{b}}\end{array}$ \\
\hline OY-W & amp (Amp) & $\begin{array}{l}\mathrm{E}^{\mathrm{c}} \\
\mathrm{H}^{\mathrm{c}} \\
\mathrm{T}^{\mathrm{c}}\end{array}$ & $\begin{array}{l}66(55)^{\mathrm{d}} \\
25(14) \\
65(48)\end{array}$ & $\begin{array}{l}- \\
- \\
-\end{array}$ & $\begin{array}{r}96 \\
100 \\
98\end{array}$ & $\begin{array}{r}96 \\
100 \\
98\end{array}$ & $\begin{array}{l}93 \\
89 \\
96\end{array}$ & $\begin{array}{l}92 \\
91 \\
94\end{array}$ & $\begin{array}{l}\text { IGS1 } \\
\text { IGS2 } \\
\text { nadE }\end{array}$ \\
\hline AY-C & amp (Amp) & $\begin{array}{l}\mathrm{E} \\
\mathrm{H} \\
\mathrm{T}\end{array}$ & $\begin{array}{l}63(51) \\
26(14) \\
59(45)\end{array}$ & $\begin{array}{l}90(88) \\
95(93) \\
89(93)\end{array}$ & $\begin{array}{c}100(100) \\
96(97) \\
91(100)\end{array}$ & $\begin{array}{l}- \\
- \\
-\end{array}$ & $\begin{array}{l}95 \\
89 \\
97\end{array}$ & $\begin{array}{l}92 \\
91 \\
95\end{array}$ & $\begin{array}{l}\text { IGS1 } \\
\text { IGS2 } \\
\text { nadE }\end{array}$ \\
\hline
\end{tabular}

${ }^{a} \mathrm{OY}$, onion yellows; AY-C, chlorante isolate of aster yellows; AYWB, aster yellows witches'-broom; CP, clover phyllody.

${ }^{\mathrm{b}}$ IGS1, intergenic sequence 1; IGS2, intergenic sequence 2; nadE; partial nadE gene.

${ }^{c} \mathrm{E}, \mathrm{N}$-terminal export leader domain; $\mathrm{H}$, major hydrophilic domain; $\mathrm{T}, \mathrm{C}$-terminal transmembrane domain.

d Nucleic acids in plain type; proteins are in parentheses. 
the JHP phytoplasma and the other AY subclade phytoplasmas also showed the diversity of the Amp-H domain. Between the JHP phytoplasma and the other AY subclade phytoplasmas, Amp-E had 46 to $55 \%$ identity, and Amp-T had 43 to $50 \%$ identity. However, Amp-H had only 14 to $24 \%$ identity, which was considerably lower than the identities of the other domains. The same results were also obtained at the nucleotide level (Table 1).

To investigate whether the sequence identities of the Amp-H domain is lower than that of intergenic regions and other genes, we calculated the nucleotide sequence identities of the putative intergenic regions (Fig. 2A; IGS1 and IGS2) and the partial sequence of nadE ( $86 \mathrm{bp}$ ) amongst JHP and other phytoplasmas. The IGS1 and IGS2 of JHP phytoplasma were about $20 \mathrm{bp}$ and about 90 bp shorter, respectively, than those of the other AY subclade phytoplasmas. The identities of IGS1 and IGS2 were slightly lower than those of amp-E or amp-T but higher than that of $a m p-\mathrm{H}$ (Table 1). The partial nadE was well conserved, with an identity of 78 to $81 \%$ (Table 1 ).

Expression and purification of JHP-Amp in E. coli. To obtain the antibody against the JHP-Amp protein, we attempted to express three combinations of the JHP-Amp protein domain in $E$. coli: the entire JHP-Amp (JHP-Amp-E/H/T), the N-terminal export leader domain and the major hydrophilic domain (JHP-Amp$\mathrm{E} / \mathrm{H})$ and the hydrophilic domain alone (JHP-Amp-H). Although it has been reported that the growth of $E$. coli harboring the entire AY amp gene was inhibited (3), E. coli harboring these JHP-amp genes did not show a growth decline. As a result, the JHP-Amp-H protein $(\approx 11.4 \mathrm{kDa})$ was expressed as a soluble protein; however, both the JHP-Amp-E/H and the JHP-Amp-E/H/T could not be successfully overexpressed (data not shown). Therefore, the JHPamp-H was overexpressed, purified, and used to obtain an antibody against the JHP-Amp protein.

Western blot analysis using the antibody against JHP Amp. Crude protein extracts were prepared from an OY-infected garland chrysanthemum (OY extract), an JHP phytoplasma-infected hydrangea (JHP extract), a healthy garland chrysanthemum, and a healthy hydrangea. These four protein fractions were subjected to western blot analysis using the antibody against JHP-Amp and the previously generated antibody against OY-Amp (16). In western blot analysis using an antibody against OY-Amp, a protein band $(\approx 25 \mathrm{kDa})$ was specifically detected in the OY extract, but was not detected in either the healthy extracts or the JHP extract (Fig. 3A). However, in western blot analysis using an antibody against JHPAmp, a protein band $(\approx 17 \mathrm{kDa})$ was specifically detected in the JHP extract, but not in either the healthy extracts or the OY extract (Fig. 3B). Though it seems that additional bands were found in lanes 2 and 3 in Figure 3B, these bands would probably be nonspecific signals because these bands are not the same size as the band identified with the antibody raised against OY-amp. Therefore they are not likely to be a cross-reactivity of that protein with the antibody raised against JHP-amp. These results suggest that JHP-Amp was expressed in the JHP phytoplasmainfected hydrangea plant. They also demonstrate that both antibodies against OY-Amp and JHP-Amp were highly specific to their respective phytoplasmal species, and did not cross-react with each other.

Immunolocalization analysis of JHP-Amp in JHP-infected floral tissues. To investigate the distribution patterns of the JHP phytoplasma in phyllody tissues, immunolocalization analysis was performed using an antibody against JHP-Amp. The paraffinembedded carpels with the stamens and the petals were cut in the vertical direction. The blue signals representing the localization of the JHP-Amp protein were detected in all phytoplasma-infected plants (Fig. 1N, O, P, Q, and R), and no signal was detected in healthy plants (Fig. 1M). Interestingly, internal morphological changes were observed in the pistil of the JHP phytoplasmainfected plant. In the healthy pistil, an ovary developed at the base, and stigmas were separated into two parts and developed a round shape (Fig. 1M). In the JHP phytoplasma-infected plant, new vascular bundles were formed at the base of the pistil instead of the ovary (Fig. 1N), and the JHP-Amp signals were detected in the newly formed vascular bundles (Fig. 1P, Q, and R). The JHPAmp signals were exclusively detected in the phloem, which is the tubular tissue next to the xylem (Fig. 1P, Q, and R). The JHPAmp signals were also detected in the stigmas that changed into leaf-like structures (Fig. 1O).

\section{DISCUSSION}

In this study, we showed that the Amp sequence of the JHP phytoplasma was different from that of the other phytoplasmas. It has previously been reported that the Amp sequences are highly divergent; for example, the hydrophilic domains of the Amps from AY-C and CP were highly divergent in both size and sequence (3), and a strong positive selection was observed in the central hydrophilic region of the Amp protein (15). However, JHP-amp showed the lowest similarity to previously known amp sequences (Table 1). Moreover, the hydrophilic region of JHPAmp was more divergent than the intergenic sequences (IGS1 and IGS2) (Table 1), which is consistent with the previous reports of the other Amp proteins $(3,16)$. Since the Amp proteins are highly divergent in their hydrophilic domains, probably mainly due to the strong selective pressure (3), it has been suggested that Amp might have a key role in phytoplasma-host interactions (15). Recently, it was reported that the Amp of OY-W formed a complex with actin and myosin proteins (components of microfilaments) of its insect vector, and the formation of this complex was correlated with insect vector specificity (37). Insect vector(s) of JHP might be different from those of other phytoplasmas because the sequence of JHP-Amp was very different from that of the Amps from other phytoplasmas. Further study involving, for example, identification of the insect vector(s) of the JHP phytoplasma and analysis of the interaction between JHP-Amp and microfilament proteins of its insect vector, would shed light on the relationships between the sequence diversity of Amp and insect vector specificity.

Although several amp genes have been cloned and sequenced, all previously cloned amp genes were derived from 'Candidatus Phytoplasma asteris' strains $(2,3,16,29)$. This study provides the first report of cloning and expression analysis of the amp gene from 'Candidatus Phytoplasma japonicum', which is phylogenetically distinct from 'Candidatus Phytoplasma asteris', but still belongs to the group I phytoplasmas. Since the amino acid sequence of JHP-Amp was unique as compared to the Amp sequences from other phytoplasmas, JHP-Amp was expected to have specificity as an antigen. An antibody against JHP-Amp did not react with OY-Amp, and an antibody against OY-Amp did not react with JHP-Amp; that is, no cross-reactions were observed between an antibody against JHP-Amp and an antibody against OY-Amp (Fig. 3). It has been demonstrated that monoclonal antibodies raised against IdpA of Western X-disease phytoplasma

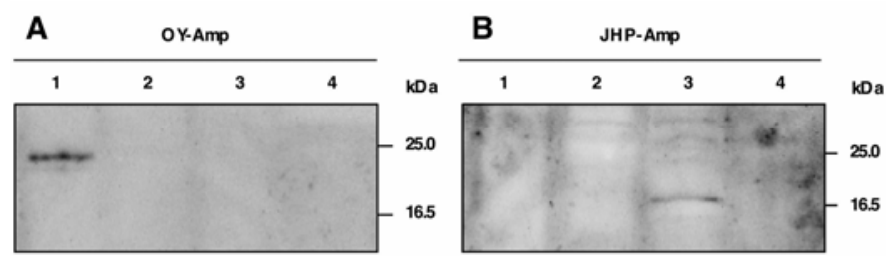

Fig. 3. Western blot analysis using an antibody raised against OY-antigenic membrane protein (Amp) (A) and Japanese hydrangea phyllody (JHP)-Amp (B). Each lane of $\mathbf{A}$ and $\mathbf{B}$ indicates the same protein extracts. Lane 1, Extract from an OY-W phytoplasma-infected garland chrysanthemum plant; lane 2, protein extracts from a healthy garland chrysanthemum plant; lane 3, protein extracts from a JHP phytoplasma-infected hydrangea plant; lane 4, protein extracts from a healthy hydrangea plant. 
(WX) reacted with peach rosette and other strains of WX, but did not react with Vaccinium witches'-broom phytoplasma (VAC), even though VAC is phylogenetically related to both WX and peach rosette, based on 16S rRNA gene sequences (7). It has also been reported that the polyclonal antibody raised against Imp of the apple proliferation phytoplasma did not react with the extract from plants infected with the closely related pear decline phytoplasma (5). These previous reports and our present study indicate that a specific antibody against the IDP of a particular phytoplasma did not always react with closely related phytoplasmas. The SecA membrane protein, which is a component of the Sec protein export system, is known as another antigen for phytoplasmas. An antibody raised against SecA of the OY phytoplasma reacts with a wide range of phytoplasmas, including JHP phytoplasma (41). Since an antibody raised against JHP-Amp reacted specifically with JHP phytoplasma, this antibody has the potential to be a useful tool for specific detection and identification.

We performed immunolocalization analysis of the JHP phytoplasma in phyllody floral organs of hydrangea plants. In previous reports, radioisotope-labeled phytoplasma specific DNA probes were used to monitor colonization pattern and population dynamics of phytoplasma infection and its relationship to subsequent symptom development (21). Immunolocalization analysis with an antibody against SecA or Amp was also used to visualize the distribution patterns of phytoplasmas in a vascular bundle and a shoot apical meristem $(18,30,41)$. Alternatively, the phytoplasmainfected plant tissue was stained with vital fluorescence dyes for bioimaging and examined under confocal laser scanning microscopy (8), and the presence of the MD phytoplasma in floral organs was confirmed by PCR (14). Transmission electron microscopy with immunolabeling (23), DAPI staining (10), or in situ hybridization employing various phytoplasma-specific oligonucleotide probes (24) were also performed for the purpose of localization of phytoplasma in infected tissues. Our results revealed that the JHP phytoplasma resided in the newly formed phloem of an abnormal pistil (Fig. 1N, O, P, Q, and R). The JHP phytoplasma was not detected in any tissues other than phloem cells. Although there are a few exceptions where the phytoplasma DNA was detected in embryo tissues other than the phloem (10), our results are consistent with previous reports that phytoplasmas do not exist in the shoot apical meristem (18).

Floral organs of the JHP phytoplasma-infected hydrangea plants showed morphological changes, such as a greening or leafy sepals (Fig. 1B, C, and D), loss of the ovary (Fig. 1K and N), leafy stigmas (Fig. $1 \mathrm{~K}$ and $\mathrm{N}$ ) or growth of the shoot apex instead of the pistil (Fig. 1D, H, and L). The biological mechanism of these disease symptoms is of interest, but it is still not known how phytoplasmas cause such malformations in the host plant flower. We hypothesize two possible mechanisms for these symptoms: phytoplasmas directly influence the flower development in a flower-developing organ, or uptake of phloem nutrients by phytoplasmas indirectly disturbs the metabolism and the flower development of a host plant. In this study, we observed that phytoplasmas inhabit the newly formed phloem of an abnormal pistil, but were not observed in an apical meristem, suggesting that the latter hypothesis was plausible. Previously, expression level changes in several flower development genes have been observed in the stolbur phytoplasma-infected tomato (32). Moreover, it has been proposed that these expressional changes were likely caused by a long-distance signal because phytoplasmas had never been detected in apical meristems (32). Generally, several flower-developing signals (e.g., sucrose, glutamine, and cytokinins) are produced in response to photoperiodic induction, and some of these are transported from the leaves toward shoot apical meristems, where floral morphogenesis takes place (9). In the case of the short-day plant Impatiens balsamina, a supply of a leaf-derived signal was needed to maintain flowering in the meristem (31), and interruption of the short-day induction by transfer into long-day conditions caused flower reversion, i.e., a switch from the floral development back to the vegetative development (31). This switch also occurred in Impatiens plants by either long-day treatment or removal of leaves that unfolded during an inductive short-day treatment (39). These previous reports suggest that signals produced in leaves play important roles in flower development. Leaf-derived signals are transported to shoot apical meristems via the phloem, where phytoplasmas are found. Thus, it is possible that phytoplasmas influence the production or the transportation of leaf-derived signals in phloem cells. To test this hypothesis, further analysis is needed to obtain time-series data on the abnormal flower development or to estimate the amount of leaf-derived signals in infected plants.

\section{ACKNOWLEDGMENTS}

We thank the Nippon Hydrangea Association for providing the JHPinfected hydrangea plants used in this study. This work was supported partly by Grants-in-Aid of Scientific Research from the Japan Society for the Promotion of Science (JSPS) (No. 09460155 and 13306004).

\section{LITERATURE CITED}

1. Altschul, S. F., Gish, W., Miller, W., Myers, E. W., and Lipman, D. J. 1990. Basic local alignment search tool. J. Mol. Biol. 215:403-410.

2. Bai, X., Zhang, J., Ewing, A., Miller, S. A., Jancso Radek, A., Shevchenko, D. V., Tsukerman, K., Walunas, T., Lapidus, A., Campbell, J. W., and Hogenhout, S. A. 2006. Living with genome instability: The adaptation of phytoplasmas to diverse environments of their insect and plant hosts. J. Bacteriol. 188:3682-3696.

3. Barbara, D. J., Morton, A., Clark, M. F., and Davies, D. L. 2002. Immunodominant membrane proteins from two phytoplasmas in the aster yellows clade (chlorante aster yellows and clover phyllody) are highly divergent in the major hydrophilic region. Microbiology 148:157-167.

4. Bendtsen, J. D., Nielsen, H., von Heijne, G., and Brunak, S. 2004 Improved prediction of signal peptides: SignalP 3.0. J. Mol. Biol. 340:783-795.

5. Berg, M., Davies, D. L., Clark, M. F., Vetten, H. J., Maier, G., Marcone, C., and Seemuller, E. 1999. Isolation of the gene encoding an immunodominant membrane protein of the apple proliferation phytoplasma, and expression and characterization of the gene product. Microbiology 145:1937-1943.

6. Bertaccini, A., Davis, R. E., Hammond, R. W., Vibio, M., Bellardi, M. G., and Lee, I. M. 1992. Sensitive detection of mycoplasmalike organisms in field collected and in vivo propagated plants of Brassica, Hdrangea and Chrysanthemum by polymerase chain reaction. Ann. Appl. Biol. 121:593599.

7. Blomquist, C. L., Barbara, D. J., Davies, D. L., Clark, M. F., and Kirkpatrick, B. C. 2001. An immunodominant membrane protein gene from the Western X-disease phytoplasma is distinct from those of other phytoplasmas. Microbiology 147:571-580.

8. Christensen, N. M., Nicolaisen, M., Hansen, M., and Schulz, A. 2004. Distribution of phytoplasmas in infected plants as revealed by real-time PCR and bioimaging. Mol. Plant-Microbe Interact. 17:1175-1184.

9. Corbesier, L., and Coupland, G. 2005. Photoperiodic flowering of Arabidopsis: Integrating genetic and physiological approaches to characterization of the floral stimulus. Plant Cell Environ. 28:54-66.

10. Cordova, I., Jones, P., Harrison, N. A., and Oropeza, C. 2003. In situ PCR detection of phytoplasma DNA in embryos from coconut palms with lethal yellowing disease. Mol. Plant Pathol. 4:99-108.

11. Cousin, M. T., and Sharma, A. K. 1986. Association of mycoplasmalike organisms (Mlos) with mild type of hydrangea-virescence - A study with 60-1,000 nm thick sections. J. Phytopathol. 115:274-282.

12. Hirokawa, T., Boon-Chieng, S., and Mitaku, S. 1998. SOSUI: Classification and secondary structure prediction system for membrane proteins. Bioinformatics 14:378-379.

13. Hiruki, C., Rong, X. D., and Deng, S. J. 1994. Hydrangea virescence, a disease associated with mycoplasmalike organism in Canada. Acta Hortic. 377:325-333.

14. Jiang, H., Wei, W., Saiki, T., Kawakita, H., Watanabe, K., and Sato, M. 2004. Distribution patterns of mulberry dwarf pytoplasma in reproductive organs, winter buds, and roots of mulberry trees. J. Gen. Plant Pathol. 70:168-173.

15. Kakizawa, S., Oshima, K., Jung, H. Y., Suzuki, S., Nishigawa, H., Arashida, R., Miyata, S., Ugaki, M., Kishino, H., and Namba, S. 2006. Positive selection acting on a surface membrane protein of the plant- 
pathogenic phytoplasmas. J. Bacteriol. 188:3424-3428.

16. Kakizawa, S., Oshima, K., Kuboyama, T., Nishigawa, H., Jung, H., Sawayanagi, T., Tsuchizaki, T., Miyata, S., Ugaki, M., and Namba, S. 2001. Cloning and expression analysis of Phytoplasma protein translocation genes. Mol. Plant-Microbe Interact 14:1043-1050.

17. Kakizawa, S., Oshima, K., and Namba, S. 2006. Diversity and functional importance of phytoplasma membrane proteins. Trends Microbiol. 14:254-256.

18. Kakizawa, S., Oshima, K., Nighigawa, H., Jung, H. Y., Wei, W., Suzuki, S., Tanaka, M., Miyata, S., Ugaki, M., and Namba, S. 2004. Secretion of immunodominant membrane protein from onion yellows phytoplasma through the Sec protein-translocation system in Escherichia coli. Microbiology 150:135-142.

19. Kanehira, T., Hirokoshi, N., Yamakita, Y., and Shinohara, M. 1996. Occurence of hydrangea phyllody in Japan and detection of the causal phytoplasma. Ann. Phytopathol. Soc. Jpn. 62:537-540.

20. Kirkpatrick, B. C. 1992. Mycoplasma-like organisms: Plant and invertebrate pathogens. The Prokaryotes. 2 ed. Vol. 4. A. Balows, H. G. Truper, M. Dworkin, W. Harder, and K. H. Schleifer, eds. SpringerVerlag, New York.

21. Kuske, C. R., and Kirkpatrick, B. C. 1992. Distribution and multiplication of western aster yellows mycoplasmalike organisms in Catharanthus roseus as determined by DNA hybridization analysis. Phytopathology $82: 457-462$.

22. Lee, I. M., Davis, R. E., and Gundersen-Rindal, D. E. 2000. Phytoplasma: Phytopathogenic mollicutes. Annu. Rev. Microbiol. 54:221-255.

23. Lherminier, J., Prensier, G., Boudon-Padieu, E., and Caudwell, A. 1990. Immunolabeling of grapevine flavescence doree MLO in salivary glands of Euscelidius variegatus: A light and electron microscopy study. J. Histochem. Cytochem. 38:79-83.

24. Lherminier, J., Bonfiglioli, R. G., Daire, X., Symons, R. H., and BoudonPadieu, E. 1999. Oligodeoxynucleotides as probes for in situ hybridization with transmission electron microscopy to specifically localize phytoplasma in plant cells. Mol. Cell Probes 13:41-47.

25. McCoy, R. E., Caudwell, A., Chang, C. J., Chen, C. C., Chiykowski, L. N., Cousin, M. T., Dale, J. L., DeLeeuw, G. T. N., Golino, D. A., Hackett, K. J., Kirkpatrick, B. C., Marwithz, R., Petzold, H., Sinha, R. C., Sugiura, M., Whitcomb, R. F., Yang, I. L., Zhu, B. M., and Seemuller, E. 1989. Plant diseases associated with mycoplasma like organisms. Vol. 5. The Mycoplasmas. R. F. Whitcomb, and J. G. Tully, eds. Academic Press, New York.

26. Morton, A., Davies, D. L., Blomquist, C. L., and Barbara, D. J. 2003. Characterization of homologs of the apple proliferation immunodominant membrane protein gene from three related phytoplasmas. Mol. Plant Pathol. 4:109-114.

27. Namba, S., Kato, S., Iwanami, S., Oyaizu, H., Shiozawa, H., and Tsuchizaki, T. 1993. Detection and differentiation of plant-pathogenic mycoplasmalike organisms using polymerase chain-reaction. Phytopathology 83:786-791.
28. Nicholas, K. B., Nicholas, H. B., Jr., and Deerfield, D. W., II. 1997. GeneDoc: Analysis and visualization of genetic variation. EMBL News. $4: 14$.

29. Oshima, K., Kakizawa, S., Nishigawa, H., Jung, H. Y., Wei, W., Suzuki, S., Arashida, R., Nakata, D., Miyata, S., Ugaki, M., and Namba, S. 2004. Reductive evolution suggested from the complete genome sequence of a plant-pathogenic phytoplasma. Nat. Genet. 36:27-29.

30. Oshima, K., Shiomi, T., Kuboyama, T., Sawayanagi, T., Nishigawa, H., Kakizawa, S., Miyata, S., Ugaki, M., and Namba, S. 2001. Isolation and characterization of derivative lines of the onion yellows phytoplasma that do not cause stunting or phloem hyperplasia. Phytopathology 91:10241029.

31. Pouteau, S., Nicholls, D., Tooke, F., Coen, E., and Battey, N. 1997. The induction and maintenance of flowering in Impatiens. Development 124:3343-3351.

32. Pracros, P., Renaudin, J., Eveillard, S., Mouras, A., and Hernould, M. 2006. Tomato flower abnormalities induced by stolbur phytoplasma infection are associated with changes of expression of floral development genes. Mol. Plant-Microbe Interact. 19:62-68.

33. Saas, A. E. 1958. Botanical Microtechnique. 3rd ed. Iowa State University Press, Ames.

34. Sawayanagi, T., Horikoshi, N., Kanehira, T., Shinohara, M., Bertaccini, A., Cousin, M. T., Hiruki, C., and Namba, S. 1999. 'Candidatus phytoplasma japonicum', a new phytoplasma taxon associated with Japanese Hydrangea phyllody. Int. J. Syst. Bacteriol. 49:1275-1285.

35. Shen, W. C., and Lin, C. P. 1993. Production of monoclonal-antibodies against a mycoplasma-like organism associated with sweet potato witches'-broom. Phytopathology 83:671-675.

36. Shiomi, T., Tanaka, M., Wakiya, H., and Zenbayashi, R. 1996. Occurrence of Welsh onion yellows. Ann. Phytopathol. Soc. Jpn. 62:258-260.

37. Suzuki, S., Oshima, K., Kakizawa, S., Arashida, R., Jung, H. Y., Yamaji, Y., Nishigawa, H., Ugaki, M., and Namba, S. 2006. Interaction between the membrane protein of a pathogen and insect microfilament complex determines insect-vector specificity. Proc. Natl. Acad. Sci. USA 103:4252-4257.

38. Thompson, J. D., Higgins, D. G., and Gibson, T. J. 1994. CLUSTAL W: Improving the sensitivity of progressive multiple sequence alignment through sequence weighting, position-specific gap penalties and weight matrix choice. Nucleic Acids Res. 22:4673-4680.

39. Tooke, F., Pouteau, S., and Battey, N. 1998. Non-reversion of Impatiens in the absence of meristem commitment. J. Exp. Bot. 49:1681-1688.

40. Vibio, M., Bertaccini, A., Lee, I. M., Davis, R. E., and Clark, M. F. 1996. Differentiation and classification of aster yellows and related European phytoplasmas. Phytopathol. Mediterr. 35:33-42.

41. Wei, W., Kakizawa, S., Jung, H. Y., Suzuki, S., Tanaka, M., Nishigawa, H., Miyata, S., Oshima, K., Ugaki, M., Hibi, T., and Namba, S. 2004. An antibody against the SecA membrane protein of one phytoplasma reacts with those of phylogenetically different phytoplasmas. Phytopathology 94:683-686. 